\title{
The Effects of Genetic Characteristics on the Survival in Myelodysplastic Syndrome
}

\section{Myelodisplastik Sendromda Genetik Özelliklerin Sağkalım Üzerine Etkisi}

\author{
(D) Atakan TEKINALP1, id Sinan DEMIRCiOĞLU1, (D) Ahmet Faruk ÇELIK², (D) Özcan ÇENELí1
}

${ }^{1}$ Necmettin Erbakan Univercity Meram Faculty of Medicine, Department of Hematology Konya, Turkey

${ }^{2}$ Necmettin Erbakan Univercity Meram Faculty of Medicine, Department of Internal Medicine, Konya, Turkey

\section{ABSTRACT}

Objective: This study aimed to evaluate the effects of genetic characteristics on the survival in patients with myelodysplastic syndrome (MDS).

Methods: This retrospective study reviewed the data on epidemiological features, main laboratory tests, International Prognostic Scoring System (IPSS) and revised-IPSS risk categories, genetic anomalies, genetic risk categories, and survival in patients who are diagnosed with MDS in our center. According to the IPSS risk categories, patients were classified into three groups as follows: "low risk," "intermediate-1," and "intermediate-2 risk and high risk." The groups were compared using the ANOVA and Kruskal-Wallis tests.

Results: The study reviewed the data of 99 patients. The mean age was $66 \pm 11.6$ years. A genetic anomaly was detected in $30.3 \%$, of which the most common was del20q (26.7\%). The median survival was 61 months [ $95 \%$ confidence interval (CI): 50.9-71] in the study population. The 5-year survival rate was calculated as $64 \%, 41 \%$, and $33 \%$ in "low risk," "intermediate-1," and "intermediate-2 risk and high risk" groups, respectively. The predicted median survival rate was 96 months (95\% CI: 47.7-144.2), 56 months (95\% CI: 34.1-77.8), and 18 months (95\% CI: 15.1-20.8), respectively, which indicate a significant difference (log-rank chi-square: 6.6; $\mathrm{p}=0.035$ ). The risk for mortality was 3.3-folds higher in the "intermediate-2 and high risk" group compared to the "low risk" group (RR: 3.3; 95\% CI: 1.2-8.6; $\mathrm{p}=0.017$ ).
ÖZ

Amaç: Çalışmamızın amacı, myelodisplastik sendrom (MDS) hastalarındaki genetik özelliklerin, sağkalım üzerine etkisini değerlendirmektir.

Yöntemler: Çalışma, retrospektif olarak tasarlandı. Merkezimizde MDS tanısı alan ve takip edilen hastaların epidemiyolojik özellikleri, temel laboratuvar testleri, Uluslararası Prognostik Skorlama Sistemi (IPSS), R-IPSS risk kategorileri, genetik anomali ve genetik risk kategorileri ve sağ kalım bilgileri kaydedildi. Hastalar IPSS risk kategorisine göre 3 gruba ayrıldı; "düşük risk", “orta-1 risk” ve "orta-2 ve yüksek risk”. Gruplar tek yön ANOVA ve Kruskal-Wallis testleri kullanılarak karşılaştırıldı.

Bulgular: Çalışmamızda 99 hasta değerlendirildi. Medyan yaş $66 \pm 11,6$ yıl bulundu. Hastaların \%30,3’ünde bir genetik anomali saptandı. En sık görülen anomali del20q $(\% 26,7)$ idi. Tüm hastalar için medyan sağkalım 61 ay [\%95 güven aralığı (GA); 50,9-71] bulundu. Beş yıllık genel sağkalım "düşük risk", "orta-1 risk" ve "orta-2 ve yüksek risk" gruplarında sırasıyla; \%64, \%41 ve $\% 33$ hesaplandı. Tahmini medyan sağkalım ise sırasıyla 96 ay $(\% 95$ GA; 47,7-144,3), 56 ay (\%95 GA; 34,1-77,8) ve 18 ay (\%95 GA; 15,1-20,8) olup sağkalım farklılığı istatistiksel olarak anlamlı bulundu (Long Rank ki-kare:6,6, p=0,035). “Düşük risk”li grupla karşılaştırıldığında ölüm riski "orta-2 ve yüksek risk"li hastalarda anlamlı olarak 3,3 kat yüksek bulundu (RR: 3,3 \%95 GA; 1,2-8,6, $\mathrm{p}=0,017)$.

Address for Correspondence: Atakan TEKINALP, Necmettin Erbakan Univercity Meram Faculty of Medicine, Department of Hematology Konya, Turkey

E-mail: atakantekinalp@hotmail.com ORCID ID: orcid.org/0000-0001-7937-4045 
Conclusion: Our study supports that risk groups that are determined by several parameters, including genetic characteristics, provide predictive information about survival in MDS.

Keywords: Myelodysplastic syndromes, prognosis, genetics, survival
Sonuç: Çalışmamız, genetik özellikler başta olmak üzere çeşitli parametreler ile belirlenen risk gruplarının MDS'de sağkalım hakkında prediktif bilgi verdiğini desteklemektedir.

Anahtar Sözcükler: Myelodisplastik sendromlar, prognoz, genetik, sağkalım

\section{Introduction}

Myelodysplastic syndrome (MDS) is a clonal hematopoietic stem cell disease, which is characterized by cytopenias due to ineffective erythropoiesis (1). The annual incidence is 12.6:100,000, which is increased in advanced age and reaches up to 50:100,000 (2). It is diagnosed after evaluations for unexplained cytopenias, particularly anemia, in older patients. Genetic characteristics are diagnostic for MDS, which also affect the identification of subtype, thus its classification. The FrenchAmerican-British classification that relies on morphological characteristics is replaced with the World Health Organization (WHO) classification by cytogenetic and molecular advances. At this point, isolated $5 \mathrm{q}$ deletion is suggested as a distinct subtype in the 2008 WHO classification (3). Additionally, genetic findings suggest disease progression. Therefore, the International Prognostic Scoring System (IPSS), revised IPSS (R-IPSS) that included details for genetic findings and cytopenias, and WHOPSS were developed $(4,5)$. Thus, these are reflected in the 2016 update and nomenclature for subtypes that were changed despite the unchanged primary definitions for MDS (6). No standard therapeutic approach is available for MDS treatment. Prognostic assessment and molecular evaluations offer a wide therapeutic spectrum from drug-free observation to immunomodulatory and hypomethylating agents and even allogeneic stem cell transplantation (7).

Herein, presented the genetic characteristics of patients with MDS and their clinical implications.

\section{Method}

This study was approved by the Ethics Committee on Medicinal Product and Non-Medical Device Research of Necmettin Erbakan University, Medicine School (approval: 14567952050/1566-27.11.2020). Patients who were followed in our center were retrospectively reviewed. The epidemiological characteristics (age, gender, and date of diagnosis), disease-related risk scoring and risk groups, genetic characteristics, complete blood count at the time of diagnosis, biochemical tests, and survival were recorded. Survival time was defined as the time from diagnosis to death for non-survivors and time from diagnosis to final assessment for survivors.

\section{Statistical Analysis}

Data were analyzed using the Statistical Package for the Social Sciences version 22.0. Descriptive statistics are given as mean \pm standard deviation. Categorical variables are presented as percentages (\%) and were assessed using the chi-square test. The ANOVA and Kruskal-Wallis tests were used to compare the groups. The survival time was calculated using the Kaplan-Meier analysis and compared between groups using the log-rank test. P-values of $<0.05$ [95\% confidence interval (CI)] was considered as statistically significant.

\section{Results}

This study retrospectively evaluated 99 patients, wherein 48 were females $(48.5 \%)$ and 51 were males $(51.5 \%)$. The mean age was $66.0 \pm 11.6$ years in the study population. Table 1 presents the disease subtype, IPSS, R-IPSS, genetic risk groups, and the employed first-line treatment modalities.

A genetic anomaly was detected in $30(30.3 \%)$ patients. The most common anomaly detected was del20q as seen in 8 (26.7\%) patients. Multiple anomalies were detected in 3 (10\%) patients, all of which showed complex karyotype features. Acute myeloid leukemia (AML) transformation was detected in 3 (3.1\%) patients of the study population. These patients were male, with loss of Y chromosome in 1 . Figure 1 presents the type and frequency of the genetic anomalies.

The median survival was 61 months (95\% CI: 50.9-71) in the study population. According to IPSS, 9 patients were in the intermediate- 2 and 1 in the high-risk group, thus the survival analyses were performed in 3 groups as "low risk," "intermediate-1," and "intermediate-2 and high risk" groups. The 5-year survival rate was calculated as 64\%, 41\%, and 33\% in "low risk," "intermediate-1," and "intermediate-2 risk and high risk" groups, respectively. A significant difference was found in the predicted median survival time (log-rank chi-square: 6.6; $\mathrm{p}=0.035$ ). Table 2 presents median survival in 3 groups. Figure 2 presents the survival plot. Effects of risk groups on survival were assessed using the Cox regression analysis.
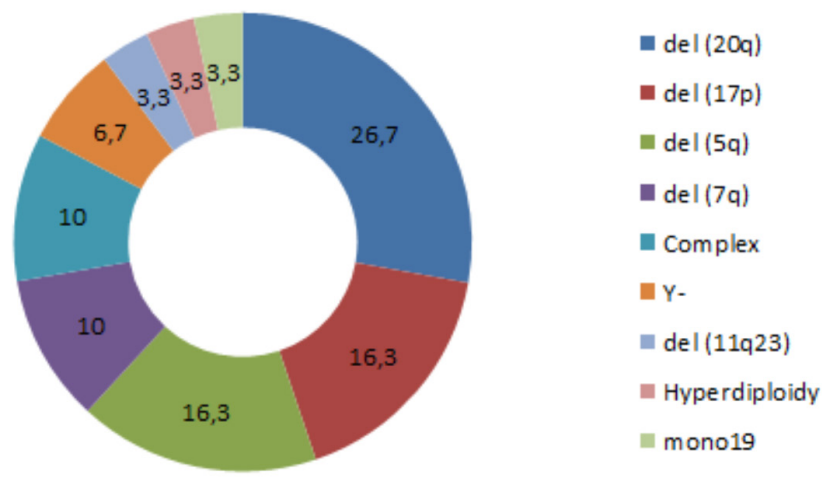

Figure 1. Frequency of genetic abnormality (\%) 


\section{Table 1. Subtype and risk groups of patients $(\mathrm{N}=99)$}

\begin{tabular}{|c|c|c|}
\hline & $\mathrm{n}$ & $\%$ \\
\hline \multicolumn{3}{|l|}{ MDS-subtypes } \\
\hline MDS-SLD & 41 & 41,4 \\
\hline MDS-MLD & 29 & 29,3 \\
\hline MDS-RS & 3 & 3 \\
\hline MDS-EB-1 & 14 & 14,1 \\
\hline MDS-EB-2 & 8 & 8,1 \\
\hline Isolated del5q & 4 & 4 \\
\hline \multicolumn{3}{|l|}{ R-IPSS } \\
\hline Very low & 27 & 27,3 \\
\hline Low & 46 & 46,1 \\
\hline Intermediate & 19 & 19,2 \\
\hline High & 6 & 6,1 \\
\hline Very high & 1 & 1 \\
\hline \multicolumn{3}{|l|}{ IPSS } \\
\hline Low & 41 & 41,4 \\
\hline Intermediate-1 & 48 & 48,5 \\
\hline Intermediate-2 & 9 & 9,1 \\
\hline High & 1 & 1 \\
\hline \multicolumn{3}{|l|}{ Genetic risk } \\
\hline Very good & 3 & 3 \\
\hline Good & 82 & 82,8 \\
\hline Intermediate & 10 & 10,1 \\
\hline Poor & 1 & 1 \\
\hline Very Poor & 3 & 3 \\
\hline
\end{tabular}

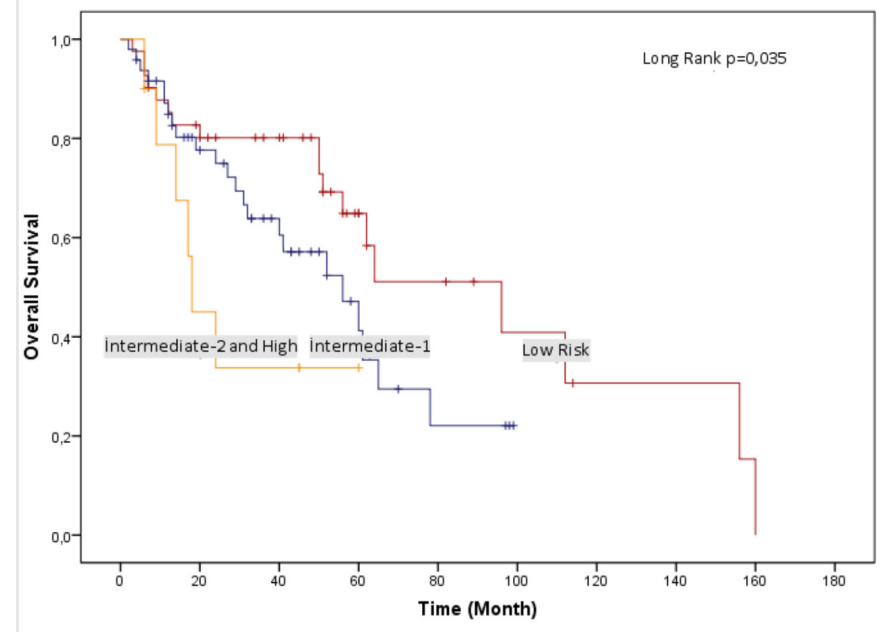

Figure 2. Overall survival according the IPSS risk groups

The risk for mortality was found as 3.3-folds higher in patients in "intermediate-2 and high risk" (RR: 3.3; 95\% CI: 1.2-8.6; $\mathrm{p}=0.017$ ), whereas 1.7-folds higher in the "intermediate-1" risk group (RR: 1.7; 95\% CI: 0.9-3.5; p=0.98) compared to "low
Table 2. Results of the overall survival according to the IPSS

\begin{tabular}{|c|c|c|c|}
\hline IPSS-risk groups & $\begin{array}{l}\text { Estimated median } \\
\text { survival (month) }\end{array}$ & $\begin{array}{l}\text { 5-years } \\
\text { OS (\%) }\end{array}$ & p-value \\
\hline $\begin{array}{l}\text { Low } \\
\text { Intermediate-1 } \\
\text { Intermediate-2 ve } \\
\text { high }\end{array}$ & $\begin{array}{l}96(95 \% \mathrm{Cl} ; 47.7-144.3) \\
56(95 \% \mathrm{Cl} ; 34.1-77.8) \\
18(94 \% \mathrm{Cl} ; 15.1-20.8)\end{array}$ & $\begin{array}{l}64 \\
41 \\
33\end{array}$ & $0.035^{*}$ \\
\hline
\end{tabular}

risk" group. No significant difference was found among the 3 groups in gender and MDS subtypes.

The median survival time was 51 months (95\% CI: 27.1-74.8) in patients with genetic anomalies, whereas 62 months (56.567.4) in those without genetic anomaly, regardless of genetic risk group; however, the difference did not reach a statistical significance (log-rank chi-square: $1.3 ; \mathrm{p}=0.242$ ).

\section{Discussion}

MDS is a clonal bone marrow disorder that is diagnosed in advanced ages. The literature suggested that $80 \%$ of cases are diagnosed at $>60$ years old (1). Some patients are diagnosed at younger ages and cases aged $<50$ years can be associated with several mutations, including SFSR2 (8). Our study revealed that the mean age was $66 \pm 11.6$ years, which correlates with the literature. Additionally, 8 (8.1\%) patients were aged $<50$ years.

In the two decades, the effects of genetics have become more apparent on prognosis, treatment selection, and survival time that have been elucidated by better characterization of genetics in MDS. Some genetic anomalies, such as 5q, 7q, and 20q deletions, and chromosome anomalies that have been introduced into the diagnostic criteria and MDS with 5q deletion have been defined as a distinct subtype among the morphological subtypes (6).

Different frequency rates have been reported for genetic anomalies in MDS; however, a genetic anomaly is detected in $80 \%$ of patients with MDS (9). Particularly, alterations at the micro-RNA level and epigenetic mutations can be detected using Next Generation Sequencing (10,11). Hosono (11) reported that chromosomal anomaly was detected in 50-60\%, whereas repeated somatic mutations in $>50$ genes were detected in 80 $90 \%$ of patients. A study by Haferlach et al. (12) detected at least one mutation in 845 (89.9\%) of 944 patients. In addition, a mutation was detected in 104 different genes, with TET2, SF3B1, ASXL1, SRSF2, DNMT3A, and RUNX a more common and RNS splicing mutations as the most common (12). In our center, chromosomal analysis was performed by conventional $\mathrm{G}$ banding method and a panel was evaluated including del (5q), del (7q), del (17p), del (20q), del (p53), del (11q23), t (15:17) fusion, and t (8:'1 by Fluorescence In Situ Hybridization. In our study, a genetic anomaly was detected in $30.3 \%$. The lower rate in our study results is thought to be due to genetic technology limitations in our center.

In our patients, the most common genetic anomaly was del (20q), which comprise $26.7 \%$ of cases with genetic anomalies. 
The primary DNA sequence, termed TERRA, is localized at 20q in the human genome and protects telomeres. Previous studies revealed that del (20q) leads to telomere loss; thus, DNA damage (13), which is not specific to MDS and can be seen in AML and other myeloproliferative diseases (14).

Cytogenetic features were classified as good, intermediate, and poor cytogenetic properties in the IPSS, whereas they were defined in more detail by adding very low and very high-risk groups in the R-IPSS (6). Del (20q) is one of the anomalies that indicate good cytogenetic characteristics (15). Our study revealed that $82.8 \%$ of cases had good cytogenetic characteristics. A large case series reported this rate at approximately $70 \%$ (5). Our analysis revealed that a lack of significant difference in patients with or without cytogenetic anomaly regardless of the risk group supports that different cytogenetic anomaly has distinct effects on prognosis. Some diagnostic features, other than cytogenetic, affect the prognosis. For instance, Malcovati et al. showed that survival was shorter in patients who are transfusion-dependent and patients with increased blast ratio (16). Thus, risk scores include cytopenia and blast ratio in addition to cytogenetic features. Moreover, the WHO-PSS also considers the MDS subtype (17). Survival is heterogeneous in MDS, which can be defined as a group of heterogeneous diseases with its clinical, laboratory, and cytogenetic characteristics. Our study found the median survival time as 61 months in the study population; however, the literature reported a survival time of 36 months and others reported a longer survival time (18).

In MDS, prognostic scoring systems are predictive for both survival and AML transformation. A multicenter study in 7,012 patients by Greenberg et al. (5) revealed that the median survival time is 8.8 years in the low-risk group and 0.8 years in the highrisk group according to the R-IPSS, whereas according to the IPSS it was $7,3.6,1.5$, and 0.7 years in the low-risk, intermediate- 1 risk, intermediate-2 risk, and high-risk groups, respectively. Our study revealed 1 patient in the high-risk group according to the IPSS and 7 patients in intermediate- 2 and high-risk groups according to R-IPSS, thus the intermediate-2 and high-risk groups were assessed as one group. Based on the grouping, the median survival time was 18 months in the "intermediate- 2 and high risk" group, whereas 56 and 96 months in "intermediate-1" and "low risk" groups, respectively. The shorter 5-year overall survival time by increasing risk correlates with the literature. Additionally, the risk for mortality was significantly higher (by 3.3 folds) in the "intermediate- 2 and high risk" group compared to the "low risk" group. Mortality risk was 1.7-fold higher in the "intermediate-1" risk group compared to the "low risk" group. These findings support that risk assessment in MDS has a significant effect on survival.

AML transformation occurs in $20-30 \%$ of patients with MDS, of which the majority are high risk (19). Additionally, time to transformation is shorter in the high and very high-risk groups according to the R-IPSS (17). Our study revealed 3 patients with AML transformation in the "low risk" group regarding the genetic and prognostic aspects.
The MDS subtypes were assessed, the most common subtype was MDS with single lineage dysplasia (MDS-SLD) by $41.4 \%$. The current literature reported that the incidence of MDS-SLD was approximate $7-20 \%$ (20). MDS registry that includes 7,012 patients by Della Porta et al. (17) revealed that the most common subtype was MDS with multi-lineage dysplasia by $29.6 \%$.

\section{Study Limitations}

Our study revealed the AML transformation in the "low risk" group and the most common MDS subtype was inconsistent with the literature. This is attributed to the single-center design and smaller sample size, which is also the main limitation of our study. Other limitations include combining "intermediate- 2 and high risk" groups in the survival analysis, insufficient survival analysis according to R-IPSS groups, and failure to assess the treatment modalities and their effects on survival.

\section{Conclusion}

However, our study can contribute to the literature by detecting the cytogenetic characteristics despite limited technical sources and emphasizing the effects of risk assessment on survival.

\section{Ethics}

Ethics Committee Approval: This study was approved by the Ethics Committee on Medicinal Product and Non-Medical Device Research of Necmettin Erbakan University, Medicine School (approval: 14567952-050/1566-27.11.2020).

Informed Consent: It has taken.

Peer-review: Externally peer reviewed.

\section{Authorship Contributions}

Concept: A.T., S.D., A.F.Ç., Ö.Ç., Design: A.T., S.D., A.F.Ç., Ö.Ç., Data Collection or Processing: A.T., S.D., A.F.Ç., Ö.Ç., Analysis or Interpretation: A.T., S.D., A.F.Ç., Ö.Ç., Literature Search: A.T., S.D., A.F.Ç., Ö.Ç., Writing: A.T., S.D., A.F.Ç., Ö.Ç.

Conflict of Interest: No conflict of interest was declared by the authors.

Financial Disclosure: The authors declared that this study received no financial support.

\section{References}

1. Kurzrock R. Myelodysplastic syndrome overview. Semin Hematol 2002;39(3 SUPPL 2):18-25.

2. Williamson PJ, Kruger AR, Reynolds PI, Hamblin TJ, Oscier DG. Establishing the incidence of myelodysplastic syndrome. $\mathrm{Br} \mathrm{J}$ Haematol 1994;87:743-5.

3. Vardiman JW, Thiele J, Arber DA, Brunning RD, Borowitz MJ, Porwit A, et al. The 2008 revision of the World Health Organization (WHO) classification of myeloid neoplasms and acute leukemia: Rationale and important changes. Blood 2009;114:937-51.

4. Sanz GF, Sanz MA, Greenberg PL. Prognostic factors and scoring systems in myelodysplastic syndromes. Haematologica 1998;83:358-68. 
5. Greenberg PL, Tuechler H, Schanz J, Sanz G, Garcia-Manero G, Solé F, et al. Revised international prognostic scoring system for myelodysplastic syndromes. Blood 2012;120:2454-65.

6. Arber DA, Orazi A, Hasserjian R, Thiele J, Borowitz MJ, Le Beau MM, et al. The 2016 revision to the World Health Organization classification of myeloid neoplasms and acute leukemia. Blood 2016;127:391-405.

7. 7. Killick SB, Carter C, Culligan D, Dalley C, Das-Gupta E, Drummond $\mathrm{M}$, et al. Guidelines for the diagnosis and management of adult myelodysplastic syndromes. Br J Haematol 2014;164:50325.

8. Ma X, Does M, Raza A, Mayne ST. Myelodysplastic syndromes: Incidence and survival in the United States. Cancer 2007;109:153642.

9. Zhang L, Padron E, Lancet J. The molecular basis and clinical significance of genetic mutations identified in myelodysplastic syndromes. Leuk Res 2015;39:6-17.

10. Üstek D, Abacı N, Sırma S, Çakiris A. New Generation DNA. Journal of Experimental Medicine 2011;1:11-8.

11. Hosono N. Genetic abnormalities and pathophysiology of MDS. Int J Clin Oncol 2019;24:885-92.

12. Haferlach T, Nagata Y, Grossmann V, Okuno Y, Bacher U, Nagae G, et al. Landscape of genetic lesions in 944 patients with myelodysplastic syndromes. Leukemia 2014;28:241-7.

13. Montero JJ, López De Silanes I, Granã O, Blasco MA. Telomeric RNAs are essential to maintain telomeres. Nat Commun 2016;7:12534.
14. Bench AJ, Nacheva EP, Hood TL, Holden JL, French L, Swanton S, et al. Chromosome 20 deletions in myeloid malignancies: Reduction of the common deleted region, generation of a PAC/BAC contig and identification of candidate genes. Oncogene 2000;19:3902-13.

15. Stehle G, Schwarb H, Passweg JR. Myelodysplastic syndromes. Ther Umsch 2019;76:497-502.

16. Malcovati L, Della Porta MG, Pascutto C, Invernizzi R, Boni $\mathrm{M}$, Travaglino E, et al. Prognostic factors and life expectancy in myelodysplastic syndromes classified according to WHO criteria: A basis for clinical decision making. J Clin Oncol 2005;23:7594-603.

17. Della Porta MG, Tuechler H, Malcovati L, Schanz J, Sanz G, GarciaManero G, et al. Validation of WHO classification-based Prognostic Scoring System (WPSS) for myelodysplastic syndromes and comparison with the revised International Prognostic Scoring System (IPSS-R). A study of the International Working Group for Prognosis in Myelodyspla. Leukemia 2015;29:1502-13.

18. Scott BL, Deeg HJ. Myelodysplastic syndromes. Annu Rev Med 2010;61:345-58.

19. Rollison DE, Howlader N, Smith MT, Strom SS, Merritt WD, Ries LA, et al. Epidemiology of myelodysplastic syndromes and chronic myeloproliferative disorders in the United States, 2001-2004, using data from the NAACCR and SEER programs. Blood 2008;112:45-52.

20. Vardiman JW, Melo JV, Baccarani M, Radich JP KH. Vardiman JW. In: WHO Classification of Tumours of Haematopoietic and Lymphoid Tissues. 2017;30-6. 